\title{
Large B-cell lymphoma mimicking iliopsoas abscess following open revision of proximal femur infected non-union: a case report
}

\author{
James McCammon ${ }^{1,4^{*}}$, Randy Mascarenhas ${ }^{2}$, Michael J Monument ${ }^{3}$, Abdul Elyousfi ${ }^{1}$ and Brad Pilkey ${ }^{1}$
}

\begin{abstract}
Background: Extranodal presentation of lymphoma is a rare occurrence. It has been postulated that chronic antigen stimulation may predispose a patient to the development of lymphoma.

Case presentation: We present a case report of a large extranodal B-cell lymphoma mimicking a postoperative abscess following surgery for an infected proximal femur nonunion in an 80-year-old Caucasian male of Italian descent.

Conclusions: This case highlights the need to consider malignancy in revision surgery, careful examination of operative specimens and the need for further understanding of the role of metal implants in chronic antigen stimulation.
\end{abstract}

Keywords: Lymphoma, Infection, Antigen stimulation, Metal implants

\section{Background}

Lymphomas can develop in any location where lymphomatous tissue exists, but extranodal presentation in the lower limb and pelvis are uncommon. We report an unusual case of large extranodal B-cell lymphoma initially presumed to be a postoperative pelvic and thigh abscess following multiple operations for an infected proximal femur nonunion.

\section{Case presentation}

An 80-year-old Caucasian male of Italian descent presented to the emergency room with a two-week history of progressive left thigh pain and swelling. The patient denied any history of trauma and stated that the pain was aggravated by weight-bearing. He denied any fevers, chills, night sweats, constitutional or neurological symptoms. He had no drug allergies and his only medication was a statin. Past medical history included hypercholesterolemia, open cholecystectomy, and prostate cancer requiring resection remotely in the past.

\footnotetext{
* Correspondence: j_mccammon@hotmail.com

${ }^{1}$ Section of Orthopedic Surgery, Health Sciences Center, University of Manitoba, Winnipeg, Manitoba, Canada

${ }^{4}$ Department of Orthopedic Surgery, University of Manitoba, 720 McDermot

Ave, AD420 Health Science Centre, Winnipeg, MB R3T 2N2, Canada

Full list of author information is available at the end of the article
}

The patient's surgical history was significant for six previous operations for a left intertrochanteric femoral fracture complicated by an infected non-union. An infectious diagnosis had been proven with Staphylococcus aureus cultured from previous operations. His most recent surgery occurred one month prior to his presentation to the emergency room and involved removal of a left trochanteric fixation nail and excision of a pseudoarthrosis, followed by an osteotomy of the left proximal femur nonunion and fixation with a proximal femoral locking plate (Figure 1). No complications were encountered during that surgery or afterwards, and the patient had been discharged home several days after surgery with instructions to avoid bearing weight on the left leg.

On physical examination, the patient was hemodynamically stable and afebrile. A general physical examination, including lymph nodes, was unremarkable. Inspection revealed pronounced firm swelling of the left thigh with slight erythema. The surgical incision on the lateral aspect of the left thigh was clean and dry. There was slight tenderness to palpation over the swollen area and left hip and knee range of motion was restricted secondary to pain in the left thigh. The patient was neurovascularly intact in his left leg. Lab results, including erythrocyte sedimentation rate, C-reactive protein, white blood cell count, and hemoglobin levels were all within normal range. Left hip radiographs showed only 


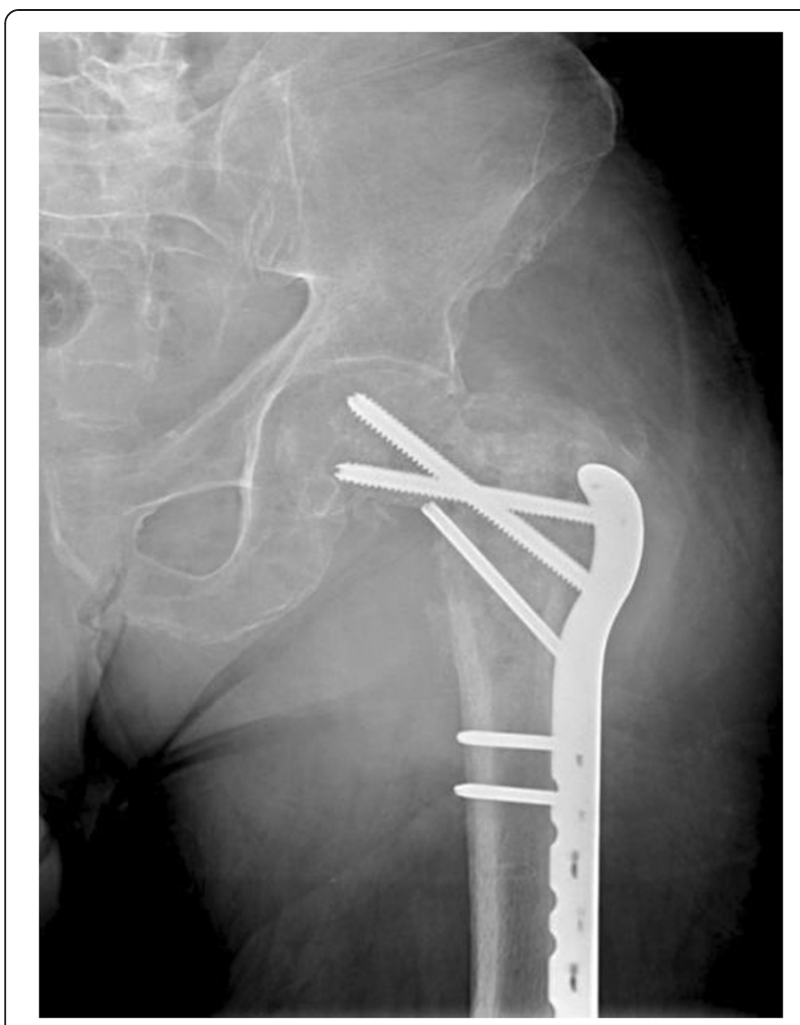

Figure 1 Anterior-posterior radiograph of the left hip. This shows a proximal femoral locking plate in good position with moth-eaten appearance of proximal femur and surrounding lysis that could be suggestive of infection or malignancy.

generalized soft tissue swelling of the left thigh with no signs of hardware failure. Computed tomography (CT) scanning of the pelvis and left thigh was suggestive of the diagnosis of a psoas abscess (Figure 2A, B).

After obtaining blood and urine cultures, the patient was admitted to hospital and broad-spectrum intravenous antibiotics were started based on recommendations from a surgical infectious disease specialist. The patient underwent incision and drainage for the left thigh abscess that same day using the previous lateral hip incision. No pus was noted intraoperatively, but a collection of thick white gelatinous tissue was noted underneath the muscle fascia of the left thigh anterior compartment and was observed to extend medially and laterally (Figure 3). Tissue specimens were sent for gram stain, aerobic and anaerobic cultures, acid fast testing, fungal cultures and cytology. The wound was then irrigated with normal saline and antibiotic beads and a hemovac drain were placed inside the wound. Intravenous antibiotics were resumed post-operatively and all cultures were negative. When swelling did not resolve within a few days after surgery, a repeat CT of the pelvis showed residual features of the presumed iliopsoas abscess extending into the left thigh. On postoperative day two, the patient underwent a second look incision and drainage through a combined ilioinguinal and lateral hip approach. A mass was noted close to the left iliac wing encasing the left femoral nerve. The femoral nerve was freed from the lesion without complication and the mass was then removed, debulked, and sent for frozen section. The frozen section revealed acute and chronic inflammation. The remaining tissue was sent for microbiology and histopathology. The wound was irrigated with normal saline and a hemovac drain was again placed before wound closure. Postoperatively, the patient was re-evaluated by the surgical infectious disease service, who proceeded to discontinue IV antibiotics and advised initiating antituberculosis therapy. This decision was based on a diagnosis of exclusion, given the negative bacterial cultures, the anatomic site of the abscess and the gross pathological features of the biopsied tissue. All screening tests for tuberculosis were negative. CT scans of the chest and abdomen were performed as part of a metastatic work up, but revealed only a large right-sided kidney cyst. The patient improved and was discharged home with oral antituberculosis therapy to be taken until definitive pathology
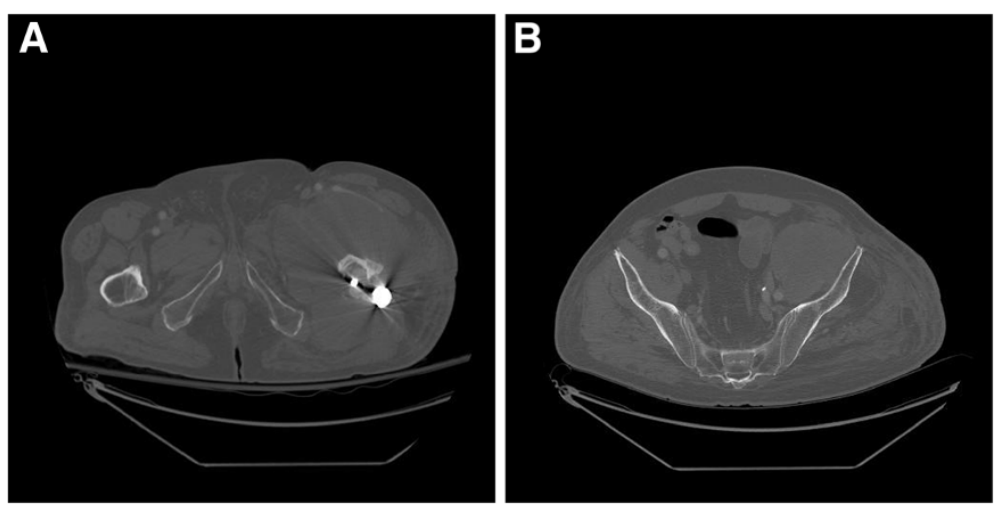

Figure 2 Axial computed tomography of pelvis. A: A dense collection/mass in anterior left thigh with lateral extension at level of the proximal femur. B: Additional cuts revealing that the collection/mass extends to the pelvis. 


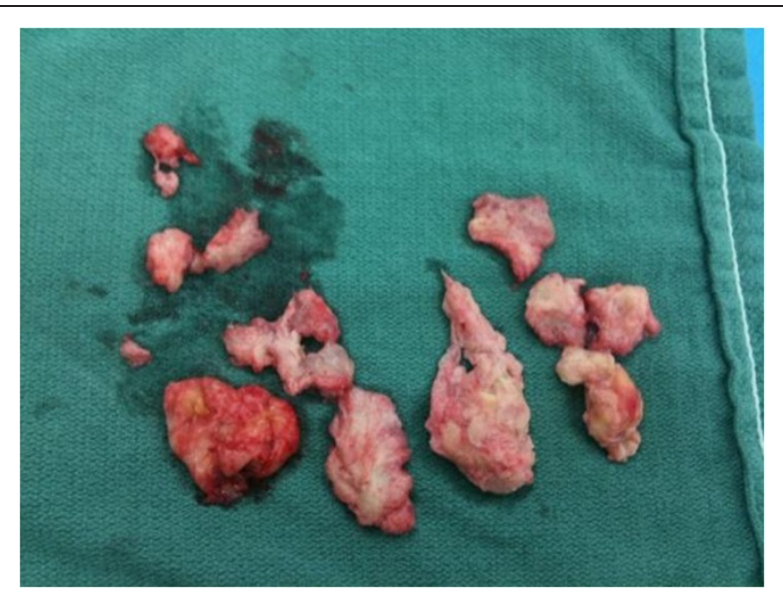

Figure 3 Intra-operative specimen. These samples were taken at the time of initial incision and drainage. Cultures were negative while pathology came back positive for B-cell lymphoma.

results were available. Two weeks later, final pathology reports supported the diagnosis of a diffuse large B-cell lymphoma. Anti-tuberculosis drugs were discontinued and a medical oncologist was consulted to initiate chemotherapy.

\section{Discussion}

Diffuse large B-cell lymphoma is the most commonly occurring lymphoma, estimated to account for 35\% of all lymphoma cases globally [1]. It typically presents in patients older than 60 years, has an aggressive natural history, and is primarily treated with systemic chemotherapy [2]. They typically develop in nodal tissue with less common development in extra-nodal tissue with estimates of approximately 1.6\% [3]. Extra-nodal sites include the gastrointestinal tract, orbit, respiratory tract, skin, bone, thyroid, central nervous system and (less commonly) the soft tissues [4,5].

Lymphomas can also involve any part of the musculoskeletal system and occasionally can manifest as a primary soft tissue mass that can be mistaken for infection or a soft tissue sarcoma [6-8]. Soft tissue lymphoma accounts for approximately $1 \%$ of malignant soft tissue neoplasms and are much more likely to present as nonHodgkin's lymphoma rather than Hodgkin's lymphoma [3]. Most patients presenting with soft tissue lymphomas are older than 50 years, with no predilection to either sex [6].

Although poorly understood, it has been postulated that primary soft tissue lymphomas may be the result of chronic antigen stimulation in an individual with a deficient immune system. In addition to inflammatory connective tissue disorders and viruses, other potential causes of a prolonged local inflammatory environment in patients undergoing orthopedic surgery include shedding of local metal ions and debris from metallic implants, radiation from radiographs and $\mathrm{CT}$ imaging, surgical trauma and infection.

Pre-clinical evidence examining the potential carcinogenic properties of metal implants found a trend towards sarcoma development in rats after 30 months when implants with a high content of cobalt, chromium or nickel were used. There was also an increase in boneassociated lymphoma development in rats with these metal implants [9]. It is believed that the local accumulation of metallic debris can cause damage to the cell membrane of macrophages with subsequent release of pro-inflammatory mediators as well as the formation of immunogenic complexes, both of which can stimulate immune system responses [10,11].

Numerous studies have explored the topic of increased cancer risk in individuals with metal implants, but have shown discordant conclusions. Gillespie et al. [12] followed a cohort of total hip arthroplasty (THA) patients and found that the incidence of lymphatic and hematopoietic malignancies was nearly twice that expected for the general population. Similarly Visuri and Koskenvuo [13] also looked at THA patients and observed an incidence of lymphomas and leukemias that was three times what was expected. However, more recent studies have shown no increase in risk of cancer [14-16]. There are approximately thirteen recorded instances of lymphoma at sites associated with metal implants in the literature (Table 1).

Chronic inflammation as a result of infection is a possible contributing factor in the development of lymphoma, as implied by studies of non-infectious consequences of osteomyelitis [28-31]. Cheuk et al. [24] also make this link, arguing that lymphoma associated with osteomyelitis shares characteristics of that associated with metallic implants. These characteristics include the fact that these solid tumors arise in the context of chronic inflammation, occur in a confined space, and have a long latency period between the onset of inflammation and the development of lymphoma.

Typically, soft tissue lymphomas present in patients older than 60 years as enlarging soft tissue masses associated with swelling or pain. In typical cases, there are usually no B symptoms such as weight loss and fever $[4,6]$. Our case features a similar presentation with an enlarging thigh mass associated with pain with the absence of B symptoms. Although the patient showed no identifiable active cause of immunocompromise, he had several risk factors for chronic antigenic stimulation including several surgeries involving metallic implants and prolonged infection after his index surgical procedure.

Despite the presence of some risk factors, the malignancy in this case could also have been coincidental. Cases have been reported of patients who underwent 
Table 1 Case reports of lymphoma in patients with metal implants

\begin{tabular}{|c|c|c|c|c|c|c|}
\hline Author, year & $\begin{array}{l}\text { Age (years)/ } \\
\text { Gender }\end{array}$ & Implant & $\begin{array}{l}\text { Time to presentation } \\
\text { (years) }\end{array}$ & Symptoms & Diagnosis & Treatment \\
\hline $\begin{array}{l}\text { McDonald [17], } \\
1981\end{array}$ & $48 / \mathrm{M}$ & $\begin{array}{l}\text { Cobalt chromium } \\
\text { plate and screws } \\
\text { in tibia }\end{array}$ & 17 years & $\begin{array}{l}\text { Aching, night sweats, } \\
\text { malaise }\end{array}$ & $\begin{array}{l}\text { Histiocytic } \\
\text { lymphoma }\end{array}$ & $\begin{array}{l}\text { Chemotherapy and } \\
\text { Radiotherapy }\end{array}$ \\
\hline $\begin{array}{l}\text { Dodion et al. } \\
{[18], 1983}\end{array}$ & $50 / \mathrm{M}$ & $\begin{array}{l}\text { Cobalt chromium } \\
\text { screw and plate }\end{array}$ & 14 months & Local pain & $\begin{array}{l}\text { Diffuse Large B-cell } \\
\text { lymphoma }\end{array}$ & $\begin{array}{l}\text { Chemotherapy and } \\
\text { Radiotherapy }\end{array}$ \\
\hline $\begin{array}{l}\text { Syed et al. [19], } \\
1997\end{array}$ & $75 / F$ & $\begin{array}{l}\text { Exeter Hip } \\
\text { Replacement }\end{array}$ & 7 years & $\begin{array}{l}\text { Increasing thigh and } \\
\text { groin pain with } \\
\text { inability to weight } \\
\text { bear }\end{array}$ & $\begin{array}{l}\text { Non-Hodgkins } \\
\text { Lymphoma }\end{array}$ & Radiotherapy \\
\hline $\begin{array}{l}\text { Rahdi et al. [10], } \\
1998\end{array}$ & $25 / \mathrm{M}$ & $\begin{array}{l}\text { Internal fixation of } \\
\text { distal tibia }\end{array}$ & 8 years & $\begin{array}{l}\text { Slow growing ankle } \\
\text { mass }\end{array}$ & $\begin{array}{l}\text { Diffuse Large B-cell } \\
\text { lymphoma }\end{array}$ & $\begin{array}{l}\text { Chemotherapy, } \\
\text { Below-knee } \\
\text { amputation }\end{array}$ \\
\hline $\begin{array}{l}\text { Rahdi et al. [10], } \\
1998\end{array}$ & $64 / F$ & Primary Total Hip & 4 years & $\begin{array}{l}6 \text { month history of pain } \\
\text { and swelling in thigh }\end{array}$ & $\begin{array}{l}\text { Diffuse Large B-cell } \\
\text { lymphoma }\end{array}$ & $\begin{array}{l}\text { Chemotherapy and } \\
\text { Radiotherapy }\end{array}$ \\
\hline $\begin{array}{l}\text { Ito et al. [20], } \\
1999\end{array}$ & $80 / F$ & Primary Total Hip & 8 years & Pain in hip & $\begin{array}{l}\text { Diffuse Large B-cell } \\
\text { lymphoma }\end{array}$ & Radiotherapy \\
\hline $\begin{array}{l}\text { Ganapathi et al. } \\
{[21], 2001}\end{array}$ & $85 / M$ & $\begin{array}{l}\text { Primary Total Hip, } \\
\text { Revision Total Hip }\end{array}$ & $\begin{array}{l}12 \text { years post THA, } 10 \text { years } \\
\text { post revision, } 14 \text { mo post } \\
\text { periprosthetic fracture }\end{array}$ & $\begin{array}{l}\text { Chronic draining sinus, } \\
\text { anorexia, lethargy, } \\
\text { drowsiness }\end{array}$ & $\begin{array}{l}\text { Diffuse Large B-cell } \\
\text { lymphoma }\end{array}$ & $\begin{array}{l}\text { Died prior to } \\
\text { radiotherapy }\end{array}$ \\
\hline $\begin{array}{l}\text { O'Shea et al. } \\
\text { [22], } 2006\end{array}$ & $75 / F$ & Primary Total Hip & 13 years & $\begin{array}{l}\text { Chronic draining sinus, } \\
\text { pain and swelling of } \\
\text { thigh }\end{array}$ & $\begin{array}{l}\text { Diffuse Large B-cell } \\
\text { lymphoma }\end{array}$ & $\begin{array}{l}\text { Chemotherapy, } \\
\text { radiotherapy, } \\
\text { excision arthroplasty }\end{array}$ \\
\hline $\begin{array}{l}\text { Hsieh et al. } \\
\text { [23], } 2007\end{array}$ & $30 / F$ & Primary Total Hip & 4 years post & $\begin{array}{l}3 \text { month history of hip } \\
\text { pain }\end{array}$ & $\begin{array}{l}\text { Diffuse Large B-cell } \\
\text { lymphoma }\end{array}$ & Chemotherapy \\
\hline $\begin{array}{l}\text { Cheuk et al. } \\
{[24], 2008}\end{array}$ & $78 / \mathrm{M}$ & $\begin{array}{l}\text { Primary Total Hip, } \\
\text { Revision } \times 2\end{array}$ & $\begin{array}{l}32 \text { years post primary TKR, } \\
16 \text { years post revision }\end{array}$ & Increasing knee pain & $\begin{array}{l}\text { Diffuse Large B-cell } \\
\text { lymphoma }\end{array}$ & Radiotherapy \\
\hline $\begin{array}{l}\text { Eskander et al. } \\
{[25], 2008}\end{array}$ & $70 / F$ & Primary Total Knee & 1 year & $\begin{array}{l}\text { Two superficial areas of } \\
\text { skin necrosis as well as } \\
\text { surrounding ecchymosis } \\
\text { and edema }\end{array}$ & $\begin{array}{l}\text { Diffuse Large B-cell } \\
\text { lymphoma }\end{array}$ & $\begin{array}{l}\text { Radiotherapy, knee } \\
\text { fusion }\end{array}$ \\
\hline $\begin{array}{l}\text { Palraj et al. } \\
\text { [26], } 2010\end{array}$ & $77 / \mathrm{M}$ & $\begin{array}{l}\text { Stainless screw } \\
\text { plate and screws } \\
\text { for tibial fracture }\end{array}$ & 7 years & $\begin{array}{l}2 \text { weeks of pain and } \\
\text { erythema, localized } \\
\text { swelling, minimal } \\
\text { warmth }\end{array}$ & $\begin{array}{l}\text { Anaplastic T-cell } \\
\text { lymphoma }\end{array}$ & Chemotherapy \\
\hline $\begin{array}{l}\text { Chaudhry et al. } \\
{[27], 2011}\end{array}$ & $76 / M$ & Primary Total Knee & 3 years & $\begin{array}{l}1 \text { week history of knee } \\
\text { pain }\end{array}$ & $\begin{array}{l}\text { Diffuse Large B-cell } \\
\text { lymphoma }\end{array}$ & $\begin{array}{l}\text { Chemotherapy and } \\
\text { Radiotherapy }\end{array}$ \\
\hline
\end{tabular}

Abbreviations: $M$ male, $F$ female, TKR total knee replacement, THA total hip arthroplasty.

total joint replacement and were found to have lymphoma on routine histopathological exams [32,33]. One study looking at retrieved femoral heads that were to be used for bone allograft found that 14 of 852 heads were highly suspicious for low-grade B-cell lymphoma. With a median of 7.2 years follow-up, one patient developed a B-cell lymphoma in a lymph vessel in the inguinal region on the contralateral side [34].

\section{Conclusion}

This case underlines the importance of considering the possibility of malignancy with revision surgery, particularly in cases that present as infectious in nature. It also re-affirms the importance of routine pathologic examination of operative specimens. As the number of joint replacements and fixation of fractures increase with life expectancy, potential long-term adverse effects of metal implants need to be further investigated.

\section{Consent}

Written informed consent was obtained from the patient for publication of this Case Report and any accompanying images. A copy of the written consent is available for review by the Editor-in-Chief of this journal.

\section{Competing interests}

The authors declare that they have no competing interests.

\section{Authors' contributions}

BP was the surgeon involved in the operations and follow-up of this patient and conceived of the report; AE contributed to data acquisition; MM contributed the data on lymphoma and was involved in editing the drafts; RM and JM contributed to data acquisition, drafting and editing the manuscript. All authors read and approved the final manuscript. 


\section{Acknowledgements}

This research supported by the University of Manitoba.

\section{Author details}

${ }^{1}$ Section of Orthopedic Surgery, Health Sciences Center, University of Manitoba, Winnipeg, Manitoba, Canada. ${ }^{2}$ Rush University Medical Center, Chicago, IL, USA. ${ }^{3}$ Department of Orthopedics, University of Utah, Salt Lake City, UT, USA. ${ }^{4}$ Department of Orthopedic Surgery, University of Manitoba, 720 McDermot Ave, AD420 Health Science Centre, Winnipeg, MB R3T 2N2, Canada.

Received: 21 December 2013 Accepted: 15 July 2014

Published: 23 July 2014

\section{References}

1. Mey U, Hitz F, Lohri A, Pederiva S, Taverna C, Tzankov A, Meier O, Yeow K, Renner C: Diagnosis and treatment of diffuse large B-cell lymphoma. Swiss Med Wkly 2012, 142:w12511.

2. Thieblemont C, Coiffier B: Lymphoma in older patients. J Clin Oncol 2007, 25:1916-1923.

3. Damron TA, Le MH, Roney MT, Vermont A, Poiesz BJ: Lymphoma presenting as a soft tissue mass. A soft tissue sarcoma simulator Clin Orthop 1999, 360:221-230.

4. Knowles B, Serpell JW: Extra-nodal lymphomas presenting as a mimic of soft-tissue sarcoma. ANZ J Surg 2003, 73:26e30.

5. Meister HP: Malignant lymphomas of soft tissues. Verh Dtsch Ges Pathol 1992, 76:140-145

6. O'Neill JK, Devaraj V, Silver DA, Sarsfield P, Stone CA: Extranodal lymphomas presenting as soft tissue sarcomas to a sarcoma service over a two-year period. J Plast Reconstr Aesthet Surg 2007, 60:646-654.

7. Malloy PC, Fishman EK, Magid D: Lymphoma of bone, muscle and skin: CT findings. AJR Am J Roentgenol 1992, 159:805-809.

8. Scally J, Garrett A: Primary extranodal lymphoma in muscle. $\mathrm{Br} J$ Radiol 1989, 62:81

9. Memoli VA, Urban RM, Alroy J, Galante JO: Malignant neoplasms associated with orthopedic implant materials in rats. J Orthop Res 1986, 4:346-355.

10. Radhi JM, Ibrahiem $K$, Al-Twigeri T: Soft tissue malignant lympohoma at sites of previous surgery. J Clin Pathol 1998, 51:629-632

11. Visuri $T$, Borg $H$, Pulkkinen $P$, Paavolainen $P$, Pukkala E: A retrospective comparative study of mortality and causes of death among patients with metal-on-metal and metal-on-polyethylene total hip prostheses in primary osteoarthritis after a long-term follow-up. BMC Musculoskelet Disord 2010, 11:78.

12. Gillespie WJ, Framptom CM, Henderson RJ, Ryan PM: The incidence of cancer following total hip replacement. J Bone Joint Surg (Br) 1988, 70:539-542.

13. Visuri T, Koskenvuo M: Cancer risk after McKee-Farrar total hip replacement. Orthopedics 1991, 14:137-142.

14. Mathiesen EB, Ahlbom A, Bermann G, Lindgren JU: Total hip replacement and cancer. A cohort study. J Bone Joint Surg (Br) $1995,77: 345-350$

15. Signorello LB, Weimin Y, Fryzek JP, Lipworth L, Fraumeni JF, Blot WJ, McLaughlin JK, Nyren O: Nationwide study of cancer risk among hip replacement patients in Sweden. J Natl Cancer Inst 2001, 93:1405-1410.

16. Visuri $T$, Pulkkinen $P$, Paavolainen $P$, Pukkala E: Cancer risk is not increased after conventional hip arthorplasty. Acta Orthop 2010, 81:77-81.

17. McDonald I: Malignant lymphoma associated with internal fixation of a fractured tibia. Cancer 1981, 48:1009-1011.

18. Dodion P, Putz P, Amiri-Lamraski MH, Efira A, de Martelaere E, Heimann R: Immunoblastic lymphoma at the site of an infected vitallium bone plate. Histopathology 1983, 6:807.

19. Syed AA, Agarwal M, Genelon G, Toner M: Osseous malignant non-Hodgkins B-cell lymphoma associated with total hip replacement. Leuk Lymphoma 2002, 43:2213-2216.

20. Ito $H$, Shimizu A: Malignant lymphoma at the site of total hip replacement. Orthopedics 1999, 22:82-84.

21. Ganapathi M, Lake DNW, Griffiths AP: Periprosthetic high-grade B-cell lymphoma complicating an infected revision total hip arthroplasty. J Arthroplast 2001, 16:229-232.
22. O'Shea K, Kearns SR, Blaney A, Murray P, Smyth HA, McElwain JP: Periprosthetic malignancy as a mode of failure in total hip arthroplasty. J Arthroplasty 2006 21:926-930.

23. Hsieh TC, Kao CH, Yen KY, Sun SS: Osteomyelitis-mimicking primary bone lymphoma at hip prosthetic site. Clin Nucl Med 2007, 32:543-544.

24. Cheuk W, Chan AC, Chan JK, Lau GT, Chan VN, Yiu HH: Metallic implant associated lymphoma: a distinct subgroup of large B-cell lymphoma related to pyothorax-associated lymphoma? Am J Surg Pathol 2005, 29:832-836.

25. Eskander MS, McPhee E, Eskander JP, Nascimento R, McCormick JJ, Hao S, Shepro D, Johnson K: A left knee wound complication by non-Hodgkins lymphoma in bilateral total knee arthroplasties. Arch Orthop Trauma Surg 2008, 128:1387-1390. Epub 2008 Jan 23.

26. Palraj B, Paturi A, Stone RG, Alvarez H, Sebenik M, Perez MT, Bush LM: Soft tissue anaplastic large T-cell lymphoma associated with a metallic orthopedic implant: case report and review of the current literature. J Foot Ankle Surg 2010, 49:561-564.

27. Chaudhry MS, Mather H, Marks A: Diffuse large B cell lymphoma complicating total knee arthroplasty: case report and literature review of the association of diffuse large B cell lymphoma with joint replacement. Acta Haematol 2011, 126:141-146.

28. Copie-Bergman C, Niedobitek G, Mangham DC, Selves J, Baloch K, Diss TC, Knowles DN, Delsol G, Isaacson PG: Epstein-Barr virus in B-cell lymphomas associated with chronic suppurative inflammation. J Pathol 1997, 183:287-292.

29. Laurent G, Pris J, Delsol G, Familiades J, Fabre J: Immunoblastic lymphoma and osteomyelitis. Lancet 1980, 1:258

30. Ostrowski ML, Unni KK, Banks PM, Shives TC, Evans RG, O-Connell MJ, Taylor WF: Malignant lymphoma of bone. Cancer 1986, 58:2646-2655.

31. Posnett DN, Collins RD, Krantz SB: Osteomyelitis and lymphoma. Lancet 1979, 2:1085.

32. Watson AJ, Cross MJ: Non-Hodgkin lymphoma as an unexpected diagnosis after elective total knee arthroplasty. J Arthroplasty 2008 23:612-614.

33. Vadivelu R, Kar N, Margetts MJ, Abdul-Cader AH: Non-Hodgkin's lymphoma as an unexpected diagnosis in a hip arthroplasty. Arch Orthop Trauma Surg 2002, 122:532-534. Epub 2002 Jul 6.

34. Zwitser EW, de Gast A, Basie MJA, van Kemenade FJ, Van Royen BJ: B Cell lymphoma in retrieved in femoral heads: a long term follow up. BMC Musculoskelet Disord 2009, 10:53.

doi:10.1186/1756-0500-7-470

Cite this article as: McCammon et al.: Large B-cell lymphoma mimicking iliopsoas abscess following open revision of proximal femur infected non-union: a case report. BMC Research Notes 2014 7:470.

\section{Submit your next manuscript to BioMed Central and take full advantage of:}

- Convenient online submission

- Thorough peer review

- No space constraints or color figure charges

- Immediate publication on acceptance

- Inclusion in PubMed, CAS, Scopus and Google Scholar

- Research which is freely available for redistribution 